\title{
Managers and Leaders in Need of Entrepreneurial Competences
}

\author{
Agnieszka Postuła, Julita Majczyk
}

\begin{abstract}
A B S T R A C T
Objective: The purpose of this article is to provide insight into how managers fit their roles and what tasks they perform. It addresses leaders and action they undertake. In particular, the study aims to focus on competences which comprise specific skills and experience, knowledge, and cognitive abilities to understand, analyse, or reason.
\end{abstract}

Research Design \& Methods: Qualitative research was done. Individual method within an ethnographic study includes an anthropological interview. In total, 16 participant in large companies were interviewed. Interviewees were managers and leaders on different organisational levels. The study used the principles of the grounded theory approach for analysing data and is based on the results of longitudinal research.

Findings: The results revealed that managers usually follow imposed goals while leaders are expected to create their own directions of organisational development. Although respect and authority might be an integral part of managers' job, as opposed to leaders, they are not indispensable. It is concluded that leaders need to deal with issues which are strategic for a company and much more important than it is in the case of managers who usually concentrate on finding solutions for everyday problems.

Implications \& Recommendations: The findings point to how competencies influence an organisational role. Even if they are interrelated, there is no need to demonstrate all of them to become a leader.

Contribution \& Value Added: This article offers a conceptualisation of how the theory corresponds with practice and points out that immaterial, immeasurable factors matter.

\begin{tabular}{lll}
\hline Article type: & research paper \\
Keywords: & competency; entrepreneurial competencies; leader; manager; \\
& knowledge; skills
\end{tabular}

JEL codes: $\quad$ 12, L2, M1

Received: 15 March 2016 Revised: 17 October 2017

Accepted: 10 November 2017

\section{Suggested citation:}

Postuła, A., \& Majczyk, J. (2018). Managers and Leaders in Need of Entrepreneurial Competences. Entrepreneurial Business and Economics Review, 6(1), 91-103. https://doi.org/10.15678/EBER.2018.060105 


\section{INTRODUCTION}

Every person takes on specific roles. Each role involves a set of competencies, behaviours or attitudes. It is all context sensitive. You need to have specific competencies when you want to lead effectively across cultures (Mendenhall, 2001), or when you want to lead children's team sports successfully. And when you already do your job, getting challenging tasks allows you to develop further your competencies or acquire new skills. That helps to build confidence in your role (Kram, 1988).

In this study, we aim to address a manager's and a leader's role by placing the focus of the research on competencies. Drawing on competencies assigned to a manager or a leader, the authors describe and detail a study based on semi-structured interviews and the grounded theory approach for analysing data. That is to explain what differs managers from leaders and what entrepreneurial competencies can be utilised by them.

Most of the research investigating competencies of managers or other groups aiming to be ones (e.g. students of business schools) focuses on evaluation and assessment (Tyrańska, 2017; Roszyk-Kowalska, 2016; Machado, Zambrano, \& Montes de Oca, 2015; Spychała, 2015). Some publications consider competencies and their applications in general (Sitko-Lutek, 2013; Tyrańska, 2015) or relations between workers' entrepreneurial attitudes and the internalisation of processes (Kosała, 2015), or education processes (Kosała, 2014; Wach, 2013). There is much less research and publications concentrating on relations between leaders, managers and entrepreneurs (Postuła \& Brzozowska, 2016) even if all these professions/roles are strongly connected to each other. Nowadays, when the era of managers seems to change dramatically (Koźmiński, 2008), there is scarcity of such research. We decided to combine leaders' and managers' perspectives and relate it to their competencies, both managerial and entrepreneurial. The purpose of this article is to provide an insight into how managers perform tasks and leaders act using their particular competencies. The whole presented analysis is based on the results of longitudinal research.

\section{LITERATURE REVIEW}

\section{Entrepreneurial and Managerial Competencies}

A competency varies depending on situations or times, it is a capability or ability used in certain circumstances (Boyatzis, 2008). Abilities as knowledge, skills and attitudes allow to perform tasks at the appropriate level (Filipowicz, 2004). It triggers specific behaviours, reveals the way of thinking. Following Woodruffe's definition (1991), a person's behaviour reinforces competent performance while aspects of the job are fulfilled.

A person can demonstrate it, which gives us an opportunity to measure his/her performance. When a person's capability of acting is consistent with individual needs, the environment expectancies, or job demands, it is said the person has reached maximum performance (Boyatzis, 1982). Job demands can derive from a role responsibilities or ongoing tasks. We divide competences into two categories: managerial and entrepreneurial ones. Those required to run a business in a successful manner are described as managerial competences, whereas a group of competences significant to the development of businesses and the implementation of entrepreneurship are entrepreneurial competences 
(Bamiatzi et al., 2015). Entrepreneurial drive and the capitalisation of entrepreneurial opportunities which are components of entrepreneurial competences have an effect on both financial and non-financial performance ( $\mathrm{Ng}, 2016)$. Boyatzis (1982) enlisted numerous competencies. Some related ones are grouped (Boyatzis, Goleman, \& Rhee, 2000).

In the entrepreneurial cluster we identify initiative - taking responsibility for selfdriven action, and efficiency orientation - setting goals, motivating people to act, focusing on tasks. The interpersonal cluster comprises: concern with impact - seeking and using methods of influence, oral presentation skills - an ability to use effective language, use of socialised power - developing formal and informal relations among people to motivate them to achieve objectives, or managing group processes - the group's identity building, developing group roles. The leadership cluster embraces conceptualisation - inductive reasoning to identify patterns and relationships, creative thinking to develop ideas and solutions, self-confidence - believing in oneself, ideas, values, and again oral presentation skills. The goal and action management cluster consists of the aforementioned initiative and efficiency orientation, concern with impact, and diagnostic use of concepts - deductive reasoning allowing to turn concepts into possibilities.

In the concept of 'emotional intelligence', Goleman (1999, pp. 48-50) grouped managerial competencies identified by Boyatzis (1982) into self-management and relationship management competencies.

In the paper from 2008, Boyatzis $(2008$, p. 7) divided competencies into three categories:

- specific skills and experience,

- knowledge,

- cognitive competencies as an ability to understand, analyse, reason.

Weber (2004) says than an organisation performs best when competencies are seen as a highly valuable asset treated as the main cause for climbing the career path by workers. According to his view, organisations ought to evaluate each person by the criteria measuring the effectiveness of the task performance. Following the Peter principle (Peter, 1975), an organisation selects a candidate for a vacancy by his or her competencies demonstrated while acting in the current role, not by the abilities expected in the intended role.

There is no easy way to verify a candidate's competency statements. Hidden information (Arrow, 1969) can play a crucial role while selecting workers, assigning them tasks. However, if competencies are proven, they add value to the whole organisation (Stewart, 1997).

\section{Manager and Leader in Theory}

A leader is a person able to influence psychological and institutional resources to motivate, trigger necessary actions (Burns, 1978). Patterns of how leaders behave, what they do and what values they indicate have an immense impact on the evolution of the management concepts. Business leaders play an active role in the development of the economic environment, being an inspiration for others to trigger their own actions. In the classic sense of that term, a leader builds the expected future state of the organisation by enabling people who are under his/her influence to take actions to achieve organisational goals. However, in the context of complex adaptive systems, a leader is not able to drive changes or control future results (Plowman et al., 2007). Hence, she/he takes on a supporting role, for example by encouraging innovative solutions. 
Leaders can be analysed in terms of the process of becoming a leader and perceived in this way by members of the environment, or by looking at them through the prism of efficiency and performance, as they affect actions taken by the management staff in the organisation. They play a symbolic role for the environment, but also act as representatives of an economic entity (O'Connell \& Bligh, 2009). To define someone a leader, we can adapt competence based approach which focuses on identifying what traits and skills are crucial to be perceived as one (Northouse, 2004; Grint, 2005). A leader has a vision of the organisation's goal, which is to define a reality (Bennis, 1989). Their responsibility is to build and maintain relationships with various groups of stakeholders (Maak \& Pless, 2006). During a crisis, they are expected to implement major changes to the organisation which would have a positive impact on the acquisition of knowledge and the involvement of employees in developing solutions to problems (Mohrman \& Worley, 2009).

Mintzberg (1975) pointed out that a manager's roles arise from formal authority. In line with the interpersonal category, a manager is a leader. As leaders, managers have to set goals, bring together the organisation's needs and the organisation's members' needs. They establish organisational and material conditions which support employees' activities, as well as motivate a team to achieve goals. Currently, managers with specific competencies compete successfully on the market. Companies have in mind that the selection of managers must be followed by creating an ability to identify, work on new, or cultivate further their competencies (Wu \& Lee, 2007).

A manager perceived as a leader is a visionary, an intelligent, moral and benevolent person who releases energy to act vested in people (Teo-Dixon \& Monin, 2007). Bennis and Nanus (1985, p. 21) noted that leaders do the right thing, whereas managers do things right.

A competence indicates the possession of knowledge, required skills, and an attitude enables a person to act effectively in a wide variety of situations or jobs (Filipowicz, 2004, p. 17). They are a cluster of categories which are related, interconnected (Filipowicz, 2004, pp. 36-37), and they can occur at any stage of a person's career.

All these elements named above allow to qualify managers and leaders as professions (Shein, 1968). A profession is understood as a set of scripts, patterns of actions in running a specific business or managing people or situations. Managers and leaders are professionals because of the proper qualifications, education and competences, not owing to individual relations or private connections. Their work is a profession because the whole community has its own ethical standards.

We investigate mangers and leaders not only considering their professional role, but also a societal role which is the second dimension of these professions in addition to the organisational one (Postuła, 2010). The societal role consists of the expectations of the outsiders - people who stay close to managers and leaders in their everyday activities. The analysed rankings are based on this perspective. In this way we got the material straight from the investigated group, as well as from their closest work companions. Considering these dimensions of the social role, we analysed how the role of a manager and a leader is constructed.

\section{MATERIAL AND METHODS}

The goal of this research was to identify social competences necessary for managers and leaders to perform their work. In particular, we focused on differences in managerial and 
entrepreneurial competences and the role they play in constructing the role of both managers and leaders. Interlocutors were selected from small, medium-sized and large companies (also international corporations) representing different branches on the Polish market.

The material presented in this article was obtained from two sources. Both of them are ongoing ethnographic projects. Ethnography, being a specific methodology, is a natural consequence of the adopted view on the social reality. This implies that the evidence collected and presented and the conclusions drawn on this basis may provide an input for multidimensional discussions, yet will not feed into establishing the one and only right course of action (Willis, 2005).

Traditionally, qualitative methods (an anthropological interview) formed the basis for this research (Jansen, 2015). An anthropological interview is a fundamental research tool helping to collect evidence in the field. It is an undirected (non-standardised and unstructured) conversation aiming to induce interviewees to talk freely about their surrounding reality. The researcher's 'anthropological mind-set' (Czarniawska-Joerges, 1992) is a desirable state of mind helping to see the stories heard as completely new and interesting phenomena on the one hand. On the other hand, it allows to ask questions which do not suggest anything to interviewees but enable them to tell their own stories.

We combined interviews collected by two researchers. Interviewees were managers and leaders on different organisational levels. Altogether, we have sixteen interviews. They were conducted in different circumstances, some at the workplace during working hours, some after work, some at respondents' homes. The longest interview lasted 25 hours, the shortest around 40 minutes. In general, we collected 212 pages of the typescript.

Drawing on competencies and other key elements of being a manager, a leader, the authors conduct an interview study with practitioners. That is to explain what differs managers from leaders and what entrepreneurial competencies can be utilised by them.

We are aware of the weaknesses of the ethnographic methods. On the one hand, we know that our sample is not big enough to abstract conclusions for the whole population. On the other hand, owing to open interviews we had a chance to immerse deeper into our field and learn the investigated group better. The advantage of this approach let us not only enumerate competences crucial for interlocutors, but also understand their importance in managerial work.

\section{RESULTS AND DISCUSSION}

\section{Draft horses and racehorses are in each good stable. [PP]}

We are to present definitions of managers and leaders in this part. Both managers and leaders have to deal with other people and they need to influence their behaviour to reach organisational goals. To cooperate with other people successfully, they have to possess a specific attitude which arises from personal competencies. We listened to several managers and leaders and we obtained stories about managing people. We also witnessed deep reflections on their everyday work. To point out how our interlocutors define managers and leaders we provide some quotations:

A manager is a person who has been given power. [TN]

A leader is a person you listen to, you follow without an official appointment. [TN] 
[Leaders], but not appointed managers, are those visionaries, innovators, experts (...) maybe I would call myself a leader more than a manager. [TN]

Managers are described as professionals with specific roles. They supposed to be coordinators of everyday work. They should also be an example for other team members. They should plan work for themselves and others, organise single tasks, control subordinates and plan the implementation. These are simple manager roles named earlier by Mintzberg (1975) or administrative functions enlisted by Fayol (1947, cited by Piotrowski, 2001).

It seems to me that I have to be able to motivate people to do something, sometimes unwanted things, to do tasks workers do not want to do, such as to stay late in the office because of tight deadlines, because something falls apart. Motivate, convince people so that they wanted to do it. Also it seems to me that we need to have the ability to communicate difficult information in a painless way. [PC]

In addition to traditional managerial functions, interlocutors noticed other virtues 'psychological' ones, as they call them - that can be helpful when managing people.

It is important to collaborate with people and understand how the group which you manage works and how to adjust workers well to do those tasks well. It seems to me that this is such a psychological approach, to extract from the person you have the potential that yields results, or to find such a person. [DR]

Social competence, interpersonal, simply to recognize and evaluate a worker's ability, not to give him a task he cannot handle, the task that makes him feel rather uncomfortable. Not to force him to do something that is not his. Be able to share work and split responsibilities in the way which makes the person who is assigned to do it feel convinced, not forced. Otherwise, he or she can do the task wrong, come back to me and I need to improve. [PC]

Managers and their co-workers (team members) also expect managers to be fair in their actions and not necessarily submissive. That means they are perceived as strong personalities that are able to influence people and organise their work. It also indicates that managers do not have to use power tactics to be successful because their virtues (like being fair or strong) make people listen and follow them. Good managers achieve their authority by being consistent. This is a very specific virtue which is also attributed to leaders. In our opinion, consistency is even more a feature of leaders than managers. Only outstanding managers can take pride in consistency/integrity - as they call it.

I want to say consistency/ integrity, you do not build it in a single moment, yes, it is the whole process, you build throughout your life, entire career, right from the beginning. Even if at the very beginning of your career you lose this integrity or consistency, do something against yourself or something unethical, something that you believe was not fair, everyone will find out about this, and I'm not talking about such decisions that you made because of the lack of knowledge, right, but when your acts are premeditated, while being conscious, or against yourself, or against the ethical principles. Firstly, you lie or cheat and such behaviour becomes a habit, and you cannot eradicate it, and secondly (...) when you lack precisely this consistency, you encounter in the course of your career more and more people who do not want to work with you, because you cheat (...). And vice versa, if you 
have followed fair, ethical path and had proper relationships with people with whom you worked, behaved professionally, not in the sense of beautiful voice, or a nice suit, but fair, consistent, you work with various people within projects in different companies, with complete strangers, but they know you, they say: 'I heard from Maciek we will work well.' [TN]

In addition to consistency, in the eyes of managers, leaders should be responsible and they are supposed to lead the team or other groups of people. Their task is to bring the future to the organisation.

According to our interlocutors, leaders play three basic roles: they should give inspiration for actions, they should present a vision (a new direction of the organisational development), as well as be selectors who decide about people joining the company. For instance, one of the respondents - a partner in his designing company - organizes trips to Venice from time to time with his co-workers (especially architects) to build a team, to relax as a 'working family', but also to inspire them with the creative surroundings and artistic places.

Following these quotations from our field, we believe that managers pursuing their career path change a lot. Depending on the organisation they represent, their development style differs. Some of them finish carriers on the level of a manager, but some move to the world of leaders. Here, we want to distinguish who a manager is and who a leader is, not by the definition but by the specific features they possess. Following Boyatzis (1982), we divided all traits mentioned by the respondents into three groups: knowledge, skills and attitude/abilities of managers. Table 1 sums up all the attributes named by our interlocutors.

\section{Table 1. Competences of managers named by interlocutors}

Knowledge/analytic: to reconcile ambitions of different people; solving problematic situations; analytic knowledge; responsiveness to dynamically changing environment; good organisation of work time; sensing who cannot operate, work efficiently; experience in the field, in the organisation; licences - certification, e.g. proven title and practice of the profession of a certified auditor; education - college, university, trainings

Skills: patience; listening; communication; self-reliance; making choices, making decisions; formulating thoughts; fast knowledge acquisition; maintaining good relationships with people; interpersonal skills to motivate people; bringing a stressful situation under control, indifference, apathy, ability to work under stress

Attitude/ability: commitment / drive (to like it and want to do this) / people who do not get bored / showing one's initiative; openness to change; open-mindedness; enthusiasm; freshness, youth, openness - desirable qualities; courage and assertiveness; distance to what you are doing; spontaneity; willingness to take responsibility for one's actions and results; flexibility

Source: own study based on the conducted interviews.

Managers also consider luck as an intrinsic feature of their actions. Success is not only defined by their individual contribution and hard work but it is also a matter of external factors. It is an interesting point of view, especially considering their engagement and long time spent at work. Thus, it seems that managers believe that luck is not just a simple coincidence but a strong power that helps them to act successfully.

The causes of our success are a good concept in close cooperation with the management of Gdynia [...], diligent work and support of Gdansk banking environment and the scientific community. With a little luck. [JJ] 
In plenty of cases to win you need to opt for something that no one else did. You need luck in business, be in the right place at the right time. Persistence is not enough. [JZ]

Our interlocutors distinguished project managers from regular managers because of some elements we are going to mention here. On the one hand, a project manager should motivate team-members but on the other hand, he should be decisive if the situation requires it. He should know everything about the teamwork, like creating a good team, understanding and managing people, finding conflict resolution and finally completing the project. A project manager as the person with a specifically defined goal needs to have nice personality, be relationship-oriented but still remember the goal of his actions, value the qualitative approach and build trust and good atmosphere in his team, as well as with his clients.

For us it is a failure if a client withdraws from a project. He does not want to continue the cooperation, right. It is a failure but a relief, too. The failure in the sense that you start to have doubt about the job performance and whether you do well. On the other hand, there is a type where the customer with whom anything won't work and you see it after some time, after a few weeks, really, after months of cooperation. [...] The customer can resign at any time. Sometimes we even feel the need to cut the customer's umbilical cord. But we have to fulfil assigned tasks. But really, the major setback for us is when the client loses confidence in the architect and stops cooperation. [PP]

What are the features distinguishing managers from leaders? As we have already mentioned there is a fine line between leaders and managers. We also classified characteristic features of leaders mentioned by interlocutors into three groups: social and technical skills, and other abilities. Owing to the skills such as comprehensive planning and operational planning, they demonstrate the ability to synthesise the areas of business including knowledge, trends, policies, and further analyse the available information or apply the data. They are able to articulate their beliefs, making valid and sound arguments, convince people to follow the vision, objectives or goals, forecast/anticipate trends or results.

Good leaders possess specific social skills and among them collaboration capabilities, the ability to understand and listen to people, supervise work, the ability to learn and acquire knowledge quickly, negotiating skills and determination. To reach goals and accomplish all tasks they also need an ability to establish relationships. However, we met some leaders with technical or analytical background and they admitted the lack of some social skills, in their opinion. Among the technical skills, we could learn that leaders show the capability of managing the direction of business development, managing finance, restructuring employment or running a specific manufacturing company. Also, entrepreneurial skills, identifying opportunities and exploiting the potential of a business entity were mentioned.

We also made an effort of putting together all the virtues of leaders listed by interlocutors and emerging from rankings, as well. They are combined in Table 2.

If we asked interlocutors about leaders' competences, usually we got quite similar stories as for managers. A few details differed but, in our opinion, very significant ones. Respondents admitted that leaders need respect from others even more than managers to reach their goals. In their opinion, it is extremely important for the organisational development from the strategic point of view (for the company, as well as for the leader). 
Table 2. Competences of leaders listed by interlocutors

Knowledge/analytic: combination of technical skills and interpersonal (managerial) - two company owners; interdisciplinarity; identifying problems in the environment; generating solutions to problems

Skills: flexibility; conceptual skills allow to structure the path of development of the organisation; comprehensive planning and operational planning; the ability to synthesise the areas of business including knowledge, trends, policies, and further analyse available information; applying data; articulating their beliefs; making valid and sound arguments; convincing people to follow the vision, objectives, goals; forecast, anticipating trends, results; collaboration capabilities; ability to understand and listen to people; supervising work; negotiating skills; ability to establish relationships; managing the direction of business development, financial management, restructuring employment; entrepreneurial skills - identifying opportunities and exploiting the potential of a business entity; marketing skills; the ability to learn, acquire knowledge

Attitude/ability: respect; sensitivity (engineer-artist); wide view, contact with others, a different point of view; consistency, integrity (fair, ethic); sympathetic; flexible; energetic; thrill-seeking; ambitious; eager to cooperate; independent; courageous; prudent; responsible; honest; determined to obtain success; stubborn

Source: own study based on the conducted interviews.

Moreover, it is the way to create authority in their closer and further environment. The factor helpful in establishing respect is more behaviour than knowledge of the leader. The leader must be a role model for his subordinates and a wider business environment. It influences his position and efficacy. The whole process is very well described in the next quotation.

At some point you build something like authority or expect others to act in obedience to your recommendations, no longer you have to show, for example, your CV and what you've done, or convince someone to do something. Each person sees your name positively [...]. In the manager's career something like building authority is an indispensable element in making any progress at all in his career, no training in new techniques of management. There are people who join my team, usually younger, who have PRINCE, B2B, various training done, CV full of trainings, but have no experience, no practice in leading projects. They do not have such authority built. Authority should be in a symbiotic relationship with certificates [...]. Okay, maybe you have authority, but you do not have the theoretical basis and also nobody will treat you seriously. [...] Nobody assigns any serious task to you, because very often project leaders or managers are selected to the company not to perform the task effectively but to make a good PR around the task. And we do the same, we choose well-known consulting companies. [TN]

While asking about the manager's profession we also heard stories about entrepreneurs. Many of our managers appeared to be owners of their companies at the same time, with several entrepreneurial features. The picture of an entrepreneur drawn by our interlocutors shows that they are people somewhere in-between. Depending on the branch in which they operate or business they run, sometimes they use only managerial skills, sometimes they must be visionaries. That is the moment where all competencies get together again and form a capacious and diverse profession of managing people. 


\section{CONCLUSIONS}

From our field material, some differences between managers and leaders emerge. First of all, managers usually follow the imposed goals, while leaders are expected to create their own directions of organisational development. Leaders usually have longer practice and are more experienced than managers. That is why, they are ready to mark out the directions of organisational development, taking into consideration not only knowledge but also all the mentioned skills. Leaders ought to build respect among people they work with. Although respect and authority might be an integral part of managers' job, they are not indispensable.

From our research one more conclusion arises: leaders need to deal with issues which are strategic for a company and much more important than it is in the case of managers who usually concentrate on finding solutions for everyday problems. To accomplish that goal managers need specific skills that do not have to be extremely creative, but high communication skills and abilities for successful teamwork. Working efficiently and ethically are their priorities for maintaining consistency in the profession. Answering the question which we rise in the title of the article, managers, leaders as well as entrepreneurs (which we cannot separate clearly) need similar competences and other individual virtues indispensable to manage people. But more than competences they need to concentrate on long-lasting goals and strong values. It is much more important for them to care about the moral attitude and safety of the organisation they work for than social skills or other useful competences. They need to base on traditional values, create safe and peaceful (as they state) environment to achieve their goals. It does not mean that competences are not important, but it emphasizes that managers, leaders and entrepreneurs need to foresee some steps ahead so they could see organisational phenomena from the wider perspective. Entrepreneurial competences seem to be more important for leaders who need to deal with risk and challenges, be strongly motivated and always look two steps ahead (Brzozowska, Glinka, \& Postuła, 2014). In the case of managers - it depends on the branch they operate in and the level of their actions. The smaller the group they manage is, the fewer entrepreneurial competencies they seem to need. However, this cannot be a common rule, as we found many exceptions and the qualitative character of the study does not allow us to draw such a conclusion. As Czarniawska (2010) states, specific times require a different type of managing people. Hard times usually generate the need for managers who teach how to exist, the times of crisis need leaders who show the path for a better life, and times for creation require entrepreneurs who are strong and can act fast. Whether we need managers, leaders or entrepreneurs the time will show soon. This could be a perfect idea for forgotten replication research (Butler, Delaney, \& Spoelstra, 2017).

\section{REFERENCES}

Arrow, K.J. (1969). The Organization of Economic Activity: Issues Pertinent to the Choice of Market versus Non-Market Allocation. In U.S. Joint Economic Committee, 91st Congress, 1st Session, The Analysis and Evolution of Public Expenditure: The PPB System (1), 59-73. Washington, DC: US Government Printing Office.

Bamiatzi, V., Jones, S., Mitchelmore, S., \& Nikolopoulos, K. (2015). The Role of Competencies in Shaping the Leadership Style of Female Entrepreneurs: The Case of North West of England, Yorkshire, 
and North Wales. Journal of Small Business Management, 53(3), 627-644. https://doi.org/10.1111/jsbm.12173

Bennis, W., \& Nanus, B. (1985). Leaders: The strategies for taking charge. New York: Harper \& Row.

Bennis, W. (1989). Managing the dream: Leadership in the 21st century. Journal of Organizational Change Management, (2)1, 6-10. https://doi.org/10.1108/09534818910134040

Boyatzis, R.E., Goleman, D., \& Rhee, K. (2000). Clustering competence in emotional intelligence: Insights from the Emotional Competence Inventory (ECI)s. In R. Bar-On \& J.D.A. Parker (Eds.), Handbook of emotional intelligence (pp. 343-362). San Francisco: Jossey-Bass.

Boyatzis, R.E. (1982). The Competent Manager: A Model for Effective Performance. New York: John Wiley \& Sons.

Boyatzis, R.E. (2008). Competencies in the 21st century. Journal of Management Development, 27(1), 5-12. https://doi.org/10.1108/02621710810840730

Brzozowska, A., Glinka, B., \& Postuła, A. (2014). Role of University in Creating Entrepreneurial Attitudes. Horyzonty Wychowania, 13(26), 51-71.

Burns, J.M. (1978). Leadership. New York: Harper \& Row.

Butler, N., Delaney, H., \& Spoelstra, S. (2017). The Gray Zone: Questionable Research Practices in the Business School. Academy of Management Learning \& Education, 16(1), 94-109. https://doi.org/10.5465/amle.2015.0201

Czarniawska, B. (2010). Trochę inna teoria organizacji. Warszawa: Poltext.

Czarniawska-Joerges, B. (1992). Exploring complex organizations. A cultural perspective. Newbury Park, London, New Delhi: SAGE Publications.

Filipowicz, G. (2004). Zarzqdzanie kompetencjami zawodowymi. Warszawa: Polskie Wydawnictwo Ekonomiczne.

Goleman, D. (1999). Inteligencja emocjonalna w praktyce. Poznań: Wydawnictwo Media Rodzina.

Grint, K. (2005). Leadership: Limits and possibilities. Basingstoke: Palgrave Macmillan.

Jansen, A. (2015). Positioning and subjectivation in research interviews: why bother talking to a researcher?. International Journal of Social Research Methodology, 18(1), 27-39. https://doi.org/10.1080/13645579.2013.845711

Kosała, M. (2015). Innovation processes as a stimulant of internationalisation process of firms. Entrepreneurial Business and Economics Review, 3(2), 65-84. https://doi.org/10.15678/ EBER.2015.030206

Kosała, M. (2014). Badanie postaw przedsiębiorczych wśród młodzieży jako fundament kształtowania postawy odpowiadającej wyzwaniom współczesnego świata. Horyzonty Wychowania, 13(28), 317-340.

Koźmiński, A.K. (2008). Koniec świata menedżerów?. Warszawa: WAiP.

Kram, K.E. (1988). Mentoring at Work: Developmental Relationships in Organizational Life. Lanham, MD: University Press of America Inc.

Maak, T., \& Pless, N.M. (2006). Responsible Leadership in a Stakeholder Society - A Relational Perspective. Journal of Business Ethics, 66(1), 99-115. https://doi.org/10.1007/s10551-006-9047-z

Machado, E.F., Zambrano, M.T., \& Montes de Oca, N. (2015). Epistemic Evaluation of the Training and Managerial Competence Development Process. Journal of Educational Psychology Propósitos y Representaciones, 3(2), 203-225.

Mendenhall, M.E. (2001). Introduction: new perspectives on expatriate adjustment and its relationship to global leadership development. In G.K. Stahl (Ed.), Developing Global Business Leaders: Policies, Processes, and Innovations (pp. 1-16). Westport, CT: Quorum.

Mintzberg, H. (1975, July-August). The Manager's Job: Folklore and Fact. Harvard Business Review, 49-61. 
Mohrman, S.A., \& Worley, C.G. (2009). Dealing with rough times: A capabilities development approach to surviving and thriving. Human Resource Management, 48(3), 431-443. https://doi.org/10.1002/hrm

$\mathrm{Ng}$, H.S. (2016). The role of transformational leadership, entrepreneurial competence and technical competence on enterprise success of owner-managed SMEs. Journal of General Management, 42(1), 23-43. https://doi.org/10.1177/030630701604200103

Northouse, P.G. (2004). Leadership: Theory and practice. London: Sage.

O'Connell, W., \& Bligh, M. (2009). Emerging from Ethical Scandal: Can Corruption Really Have a Happy Ending?. Leadership, 5(2), 213-235. https://doi.org/10.1177/1742715009102935

Peter, L.J. (1975). Recepta Petera. Warszawa: Książka i Wiedza.

Piotrowski, W. (2001). Organizacje i zarządzanie - kierunki, koncepcje, punkty widzenia. In A.K Koźmiński \& W. Piotrowski (Eds.), Zarzq̨dzanie. Teoria i praktyka (pp. 615-765). Warszawa: PWN.

Plowman, D.A., Solansky, S., Beck, T.E., Baker, L., Kulkarni, M., \& Travis, D.V. (2007). The role of leadership in emergent, self-organization. The Leadership Quarterly, 18(4), 341-356. https://doi.org/10.1016/j.leaqua.2007.04.004

Postuła, A., \& Brzozowska, A. (2016). Przedsiębiorczość i edukacja: podobieństwa i różnice przedsiębiorców, menedżerów i liderów. Edukacja Ekonomistów i Menedżerów: problemy, innowacje, projekty, 3(41), 133-148.

Postuła, A. (2010). Informatycy i organizacje. Warszawa: WAiP.

Roszyk-Kowalska, G. (2016). Chosen methods and tools for measuring managerial competencies. Journal of Human Resource Management, 19(2), 56-62.

Sitko-Lutek, A. (2013). Kompetencje menedżerskie w kontekście innowacyjności przedsiębiorstw. Annales Universitatis Mariae Curie-Skłodowska. Sectio H. Oeconomia. 47(1), 141-148.

Spychała, M., \& Matejun, M. (2015). Badanie ocen wybranych kompetencji menedżerskich studentów WOiZ Politechniki Łódzkiej. Marketing i Rynek, 5(CD), 1274-1293.

Stewart, T.A. (1997). Intellectual capital. London: Nicholas Brealey Publishing.

Teo-Dixon, G., \& Monin, N. (2007). Guru of Gurus: Peter Drucker, Logology, and the Ultimate Leader. Journal of Management Inquiry, 16(1), 6-17. https://doi.org/10.1177/1056492606294637

Tyrańska, M. (2017). Rola oceny kompetencji kadry menedżerskiej w organizacji procesowej. Przegląd Organizacji, 4, 61-66.

Tyrańska, M. (2015). Teoretyczne modele zarządzania kompetencjami menedżerskimi. Ekonomika i Organizacja Przedsiębiorstwa, 4, 3-13.

Wach, K. (2013). Edukacja na rzecz przedsiębiorczości wobec współczesnych wyzwań cywilizacyjnogospodarczych. Przedsiębiorczość-Edukacja, 9, 246-257.

Weber, M. (2004) Racjonalność, władza, odczarowanie. Poznań: Wydawnictwo Poznańskie.

Willis, P. (2005). Wyobraźnia etnograficzna. Kraków: Wydawnictwo Uniwersytetu Jagiellońskiego.

Woodruffe, C. (1991, September). Competent by any other name. Personnel Management, 30-33.

Wu, W.W., \& Lee, Y.T. (2007). Developing global managers' competencies using the fuzzy DEMATEL method. Expert Systems with Applications, 32(2), 499-507. https://doi.org/10.1016/j.eswa.2005.12.005 


\section{Authors}

The contribution share of authors is equal and amounted to $50 \%$ each of them.

\section{Agnieszka Postuła}

Doctor of Economic Science in Business Studies (Faculty of Management, University of Warsaw, Poland). Master in Management (Faculty of Management, University of Warsaw, Poland).

Correspondence to: Agnieszka Postuła, PhD, Uniwersytet Warszawski Wydział Zarządzania, ul. Szturmowa 1/3, 02-678 Warszawa, Poland, e-mail: apostula@wz.uw.edu.pl

\section{Julita Majczyk}

Doctor of Economic Science in Business Studies (Faculty of Management, University of Warsaw). Bachelor of Arts in Business Economics and Enterprise (University of the West of Scotland, Business School, Scotland). Master in Economics (Jagiellonian University, Poland).

Correspondence to: Julita Majczyk, PhD, Uniwersytet Warszawski Wydział Zarządzania, ul. Szturmowa 1/3, 02-678 Warszawa, Poland, e-mail: jmajczyk@wz.uw.edu.pl

\section{Copyright and License}

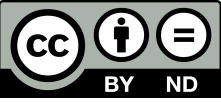

This article is published under the terms of the Creative Commons

Attribution - NoDerivs (CC BY-ND 4.0) License

http://creativecommons.org/licenses/by-nd/4.0/

Published by the Centre for Strategic and International Entrepreneurship - Krakow, Poland

Ministry of Science The copyediting and proofreading of articles in English is financed in the framework and Higher Education of contract No. 799/P-DUN/2017 by the Ministry of Science and Higher Education of 
